\title{
BRIEFING: BURUNDI'S ELECTORAL CRISIS - BACK TO POWER-SHARING POLITICS AS USUAL?
}

\author{
STEF VANDEGINSTE ${ }^{\star}$
}

ON 24 APRIL 2015, THE RULING PARTY Conseil national pour la défense de la démocratie - Forces pour la défense de la démocratie (CNDD-FDD) designated incumbent President Pierre Nkurunziza as its candidate for the forthcoming presidential elections, despite the fact that he had already completed two terms in office. The announcement that Nkurunziza planned to take a third term triggered an unprecedented series of demonstrations in Bujumbura, Burundi's capital city. Two months later, the country experienced several weeks of violent confrontation between the police and primarily young urban protesters, a failed coup d'état, and repeated delays of the elections. Around seventy people were killed in the pre-electoral violence and close to 100,000 people crossed the border, mostly to Rwanda and Tanzania. Despite international pressure and mediation, no genuine political dialogue between supporters and opponents of President Nkurunziza's third term took place.

This briefing sheds light on the trigger of the violence as well as the longer-term context of the ongoing crisis in Burundi. The Arusha Peace and Reconciliation Agreement of August 2000 is a major point of reference for the analysis of the contestation around President Nkurunziza's thirdterm ambitions, and for the larger picture of Burundi's transition process. The Arusha Agreement was the first in a series of peace agreements that put an end to over a decade of civil strife, which was in important ways an identity-based conflict. This negotiated transition from conflict to peace was based on two types of power sharing. On the one hand, it involved a classic deal to share political and military positions between incumbents and insurgents. On the other, and to a greater extent than anywhere else on the African continent, consociational mechanisms were used to re-engineer state institutions on the basis of ethnic power sharing.

* Stef Vandeginste (stef.vandeginste@uantwerpen.be) is a lecturer at the Institute of Development Policy and Management, University of Antwerp, Belgium. This briefing was finalized on 30 June 2015. 
For many years, Burundi was seen as a success story demonstrating the use of power sharing in resolving internal armed conflict. This briefing analyses the current crisis against the background of the remarkable resilience of the power-sharing model thus far. It also considers the risks of the current crisis for the sustainability of ethnic pacification. Does it signal the "end of Arusha" as many observers seem to fear? Finally, the briefing also highlights the way in which the current crisis reveals some of the perverse effects generated by the repeated use of power sharing between incumbents and opponents. Most political actors have internalized power-sharing negotiations as an alternative means to gain access to power when the ballot box does not allow them to do so. This also suggests a growing tension between power sharing and electoral processes.

In explaining the roots of the current crisis, the briefing gives considerable weight to the country's recent history. In 2005, Burundi held its first post-conflict elections, which generally were seen as free and fair, and which the former Hutu-dominated rebel movement CNDD-FDD won, having only laid down its arms one year earlier. Pierre Nkurunziza, a Hutu of mixed ethnic descent whose father was killed during the 1972 massacres, was elected President of the Republic by the two chambers of Parliament. The second post-conflict general elections were held in 2010. After the first round of local elections, most opposition parties boycotted the remainder of the elections, thus offering an overwhelming victory to CNDD-FDD and President Nkurunziza. In many ways, these polls paved the way for the current crisis. CNDD-FDD's dominant position allowed it to eliminate parliamentary opposition, to divide and rule over opposition parties which it systematically split into a "real" and a government-friendly wing, to establish an electoral commission that lacked the legitimacy to prepare inclusive elections in 2015, and gradually to reduce the democratic space available to Burundi's independent media and civil society. Seen from this perspective, the current crisis is the culmination of a longer-term process that is leading toward the establishment of a military-dominated, one-party system.

\section{Long live the constitution! The fall-out of constitutional ambiguity}

Burundi's constitution of 18 March 2005 was drafted during the Arusha peace talks (1998-2000). The Arusha Agreement contained a remarkably detailed constitutional blueprint for the post-transition period. One of its provisions stated that the president 'shall be elected for a term of five years, renewable only once' and unambiguously added that 'No one may serve more than two presidential terms'. Another provision stated that 'the president shall be elected by direct universal suffrage' but that 'the first posttransition president shall be elected by the national assembly and the senate'. In 2004, when the transitional legislature adopted the draft 2005 
constitution, an unintended ambiguity slipped into the text. As a result, article 96 of the constitution states the president is directly elected for a term of five years, renewable only once. Article 302, however, states that 'exceptionally' the first post-transition president shall by indirectly elected by the national assembly and the senate. Supporters of a third term for President Nkurunziza argue that the exception in article 302 not only refers to the modality of the presidential election but to the whole of article 96 . On that basis, the case was made that the term limit did not apply to the first post-transition presidential term and that Nkurunziza was eligible to run for a third term in 2015 without amending or violating the constitution.

Throughout the crisis, an important part of the political debate centred on this legal issue, constitutional interpretation becoming an important element in the political strategy and discourse of domestic actors (Nkurunziza supporters and opponents) as well as international actors (in particular the heads of state of the East African Community). Quite paradoxically, respect for constitutional legality was advocated by all sides. Third-term opponents insisted that the Arusha Agreement prevailed over the constitution or that, at the very least, the constitution must be interpreted in light of the Arusha Agreement. Third-term supporters argued that the constitution was the supreme law of the country and that the Arusha Agreement was no more than one political deal in a series of peace accords.

In order to legitimize Nkurunziza's candidacy, CNDD-FDD senators brought the case to the Constitutional Court, which rendered a strongly contested judgement on 4 May $2015 .{ }^{1}$ While the court acknowledged the constitutional legal value of the Arusha Agreement, for the first time in Burundi's legal history, it nevertheless concluded that the latter must be interpreted as allowing President Nkurunziza to run for a third term in office because of the ambiguity in the wording of the 2005 constitution. The legitimacy of the court ruling was strongly contested, in particular because, during the court's ongoing deliberations, the vice-president of the court fled the country, citing intimidation by Nkurunziza supporters. After the court ruling, President Nkurunziza specified his intention to run for a final term, but third-term opponents feared that if re-elected he might seek to change the constitution and remove presidential term limits completely. ${ }^{2}$

1. See Stef Vandeginste, 'Droit et pouvoir au Burundi: un commentaire sur l'arrêt du 4 mai 2015 de la Cour Constitutionnelle dans l'affaire RCCB 303', in Filip Reyntjens et al. (eds), L'Afrique des Grands Lacs: Annuaire 2014-2015 (Antwerp University Press, Antwerp, forthcoming 2015), <https://www.uantwerpen.be/images/uantwerpen/container2143/files/DPP\%20Burundi/ Constitution/Cour \%20Constitutionnelle/CC\%202005/RCCB303\%20commentaire.pdf> (18 June 2015).

2. According to 2014 Afrobarometer data, 62 percent of Burundians support presidential term limits, a significant increase compared to earlier 2012 data (51 percent support). See Boniface Dulani, 'African publics strongly support term limits, resist leaders' efforts to extend their tenure' (Afrobarometer, Dispatch No. 30, 25 May 2015). 
Indeed, there is a clear risk that President Kagame's attempt to revise the Rwandan constitution before the presidential elections of 2017, if successful, could encourage his Burundian counterpart to do likewise.

\section{Profile of the anti-Nkurunziza camp}

Third-term opponents included a wide range of political and societal actors. The anti-third-term campaign was initially launched by a group of civil society leaders. An important part of their stated motivation was the safeguarding of the Arusha Agreement as a foundational document of Burundi's post-conflict state and society. For them, a third term would inevitably signal the end of Arusha. Many urban youth presumably took part in the demonstrations for a variety of other reasons as well, essentially relating to the failure of the CNDD-FDD-dominated coalition governments to offer them a tangible peace dividend. The success of the protest movement in Burkina Faso that led to the fall of Blaise Compaoré in October 2014 further inspired the demonstrators. ${ }^{3}$ While most visible in the capital city, the opposition against a third presidential term also made it into Burundi's rural areas when the Catholic church repeatedly and in an exceptionally outspoken manner called upon the Barundi to reject their 'enslavement' by leaders hungry to remain in power. ${ }^{4}$

Finally, and more important than the role played by a plethora of divided opposition parties, opposition against Nkurunziza's third term also came from within his own party CNDD-FDD. In October 2014, at a time when the incumbent president had not yet confirmed his intention to run, top party officials of the civilian and the military wings within CNDD-FDD suggested considering a "plan B" should the party decide not to nominate Nkurunziza. This was the signal for the president and his closest allies, generals Adolphe Nshimirimana and Alain-Guillaume Bunyoni, to start preparing "plan A" as the only possible option. Decision making within the party was adapted for the occasion. The Committee of the Wise - an informal party body shrouded in secrecy and composed of selected party officials - would take the final decision, to be endorsed by a party congress. In January 2015, internal dissidence was made public for the first time when a former CNDD-FDD senator, allegedly supported by a large number of party members, requested Nkurunziza not to run. The senator was immediately expelled from the party. In February, a confidential report of the

3. See Marie-Soleil Frère and Pierre Englebert, 'Briefing: Burkina Faso - The fall of Blaise Compaoré', African Affairs 114, 455 (2015), pp. 295-307.

4. Notably, in order to justify the continuation of his rule and challenge the Catholic church leadership, born-again Christian Nkurunziza increasingly referred to the divine predestination of his fate to run the country. Allegedly with the help of God, he narrowly escaped death on two occasions during the civil war. 
National Intelligence Service (SNR) advising Nkurunziza not to run was leaked. ${ }^{5}$ General Godefroid Niyombare, head of the SNR, was immediately dismissed. In March, about seventeen senior party officials, including the presidential spokesperson, published an open letter rejecting Nkurunziza's third term. They were expelled from the party and several of them, including a provincial governor, were dismissed.

An intimidation campaign was also launched against undisclosed thirdterm opponents within the party. Attempts at replacing the speaker of the national assembly and the second vice-president of the Republic (both of them Hutu from CNDD-FDD) were unsuccessful. They were, however, removed from the Committee of the Wise. None of the internal (disclosed or undisclosed) CNDD-FDD opponents of the third term were put on the party's electoral lists for the legislative or local elections. According to presidential advisers, most of the dissidents in fact started opposing the third presidential term as soon as it became clear that they would not be selected as candidates in the forthcoming elections. ${ }^{6}$ There is no doubt that part of the internal resistance was indeed driven by opportunism and that several CNDD-FDD officials kept their cards close to their chest in order to be able in the end to choose the victorious side. By the time of the party congress at the end of April, Nkurunziza had eliminated internal opposition from the party's decision-making structures, but had also split his own party into two factions.

\section{The failed coup d'état}

On 13 May, after fifteen days of protests, former SNR chief Niyombare staged a coup d'état attempt while President Nkurunziza was in Dar es Salaam about to attend a special East African Community (EAC) summit on the situation in Burundi. The events that took place in Bujumbura seemed to be a replica of previous developments in October 2014 in Ouagadougou, Burkina Faso. Riding the waves of street protests against a third term, dissident military officers tried to oust the incumbent president, prompting large crowds to celebrate the end of an era. Niyombare addressed the nation as leader of the self-appointed Committee for the Restoration of National Harmony, seconded by Cyrille Ndayirukiye. The composition of the coup leadership was a nice illustration of Burundi's

5. Service national de renseignements (SNR), 'L'éventuelle candidature du Président Nkurunziza au troisième mandat est-elle constitutionnelle?' (Note de renseignement, 13 February 2015), <https://www.uantwerpen.be/images/uantwerpen/container2143/files/DPP\% 20Burundi/Elections/2015/Rapports\%20d'observation $\% 20$ et $\% 20$ analyses/SNR-NoteRenseignement-130215.pdf> (30 June 2015).

6. Interview, member of the CNDD-FDD party directorate, telephone interview, 28 April 2015. 
power-sharing model. While Niyombare was a Hutu and former CNDD-FDD rebel, Ndayirukije was a Tutsi and former minister of defence under President Pierre Buyoya, who ruled the country from 1987 until 1993 and from 1996 until 2003, twice after a coup d'état. While some, but not all, opposition parties welcomed the coup, civil society leaders had some difficulty in finding the right balance between, on the one hand, deploring the use of unconstitutional means to accede to power and, on the other, its enthusiasm at reaping the fruits of the anti-third-term protests. Although some regional heads of state, in particular President Kagame of Rwanda, were not supportive of Nkurunziza's third-term ambitions, the EAC summit had no choice but to condemn the coup and call for a return to constitutional order.

About twenty-four hours later, the coup attempt failed. As in the case of several other failed and successful coup attempts in the history of Burundi, the truth about the failed coup may well never be told. It is clear, however, that despite their military seniority the coup plotters made some strategic mistakes. Niyombare deposed Nkurunziza in a statement transmitted over some private radio stations, while the coup plotters had omitted to take control of the national broadcaster, airport, presidential palace and the central bank, the usual primary targets of a successful coup. A possible explanation is the role played by the army chief of staff, General Prime Niyongabo (Hutu, CNDD-FDD). ${ }^{7}$ A first possible scenario is that Niyongabo kept up the appearance of supporting the coup while informing Nkurunziza of the plans, and that the two decided to "tolerate" the coup without giving up control over the most strategic points, in order to identify internal dissidents and to justify the subsequent repression of mutineers and their supporters. The immediate closure of a number of independent radio stations, all of which opposed the third term, lends support to this scenario. A second possible scenario is that Niyongabo himself had planned a coup d'état but was taken by surprise by Niyombare's premature attempt to topple Nkurunziza in his absence. Unsuccessful negotiations that took place during the night of 13-14 May, allegedly over the leadership in the post-Nkurunziza era, lend support to that scenario.

Whatever the background machinations, the coup ultimately lacked the coordination and control necessary to succeed. On 15 May, a number of coup plotters, including Ndayirukiye, were arrested, while others, including Niyombare, escaped and managed to leave the country clandestinely. President Nkurunziza returned to Burundi overland, which he would not have been able to do without active Tanzanian support. At a second extraordinary EAC summit on 31 May, which the Burundian president did not

7. Interviews, a member of the CNDD-FDD Committee of the Wise, opposition leaders and local journalists, telephone interviews, and email correspondence, 15-19 May 2015. 
attend, President Kikwete of Tanzania supported Nkurunziza, much to the dissatisfaction of President Kagame of Rwanda, who boycotted the meeting. At the time of writing, rumours circulated that Niyombare was preparing a violent return to power from Rwandan territory, with the support of other former CNDD-FDD leaders in exile, including Hussein Radjabu. ${ }^{8}$ Together with Adolphe Nshimirimana, Radjabu had brought Nkurunziza to power within the CNDD-FDD rebel movement, but fell into disgrace and was arrested and sentenced to a lengthy prison term in 2007. Early in March 2015, Radjabu escaped from prison without much difficulty, yet another sign of Nkurunziza's failure to control his own security apparatus. After the coup, and in the run-up to the first election day, the Rwandan capital city Kigali hosted more and more Burundian dissidents. This adds to the potential for an escalation of the tensions between Rwanda and Burundi in the months to come.

\section{First election day}

The first in a series of legislative, local, and presidential elections was originally scheduled for 26 May. Because of the dire security situation and under international pressure, the government delayed the elections on three occasions, but refused to go beyond the constitutional five-year time frame. Presidential elections were pushed back to 15 July, while legislative and local elections were held on 29 June. In the run-up to this first election day, demonstrations came to an end but an increasing number of grenade attacks in the capital city as well as in smaller provincial towns signalled the next step in the escalating crisis.

Five days before the 29 June election day, most of the civil society organizations, as well as the "real" (as opposed to the government-friendly) opposition parties, announced a boycott of the elections. As a result, the situation after the first round of the 2015 elections was strikingly similar to the one that prevailed after the 2010 local elections, when the opposition also boycotted the remainder of the electoral process. However, the 2015 boycott received much greater support from most of Burundi's international partners. Belgium - Burundi's main bilateral donor - formally announced it would not recognize the results of the legislative and local elections. ${ }^{9}$

Contrary to the United Nations, the African Union and the European Union did not dispatch election observers. Somewhat surprisingly, no

8. See, for example, the statements made by General Philbert Habarugira, one of the coup plotters, Tuhiro Newus, 'Interview Général Philbert Habarugira', 26 June 2015, <https://www. youtube.com/watch?v=DXVOe6i0mJo > (30 June 2015).

9. Chambres des représentants de Belgique, Compte rendu intégral séance plénière (Chambres des représentants de Belgique, Brussels, 25 June 2015), p. 27. 
major security incidents were reported on the election day. Voter turnout varied importantly. While turnout was very high in most rural areas, it was very low in Bujumbura. According to the opposition and civil society, this proved the success of their boycott. According to government officials, this was due to a climate of fear created by the opposition. The fact that many voters tried to remove the ink from their finger in order not to be "sanctioned" for participating in the elections lends some support to that argument.

\section{The resilience of ethnic power sharing}

Burundi's electoral crisis reveals the best and the worst of power sharing as a conflict resolution mechanism. In the next section, we analyse the ongoing crisis against the background of the repeated use of power sharing between incumbents and opponents. First, we look at what the crisis tells us about the effectiveness and durability of ethnic power sharing. Indeed, Burundi has been cited - and praised - as the most successful African case of the use of consociational power sharing in negotiating a transition from conflict to peace. ${ }^{10}$

Ethnic antagonism and the 'politics of distrust' ${ }^{11}$ prevailed for almost four decades after a single-party republic was created in 1966, shortly after independence. Until the end of the Cold War, members of the Tutsi ethnic minority group controlled Burundi's government and military. Repeated uprisings by the demographic Hutu majority group were violently suppressed. Events in 1972, often referred to as a selective genocide against the Hutu, ${ }^{12}$ continue to shape contemporary elites' perception of Burundian history. The assassination in October 1993 by Tutsi army officials of Melchior Ndadaye (Hutu), the first democratically elected president, gave rise to large-scale inter-ethnic massacres, some of which are referred to as a genocide against Tutsi, ${ }^{13}$ and to a civil war between the Tutsidominated army and predominantly Hutu rebel movements including the CNDD-FDD (at a time when genocide was unfolding in neighbouring Rwanda).

Contrary to what happened in Rwanda, the war in Burundi came to an end through negotiations, not through a military victory. A backbone of

10. René Lemarchand, 'Consociationalism and power sharing in Africa: Rwanda, Burundi and the Democratic Republic of the Congo', African Affairs 106, 422 (2007), pp. 1-20.

11. Nic Cheeseman, 'The internal dynamics of power sharing in Africa', Democratization 18, 2 (2011), pp. 336-65.

12. René Lemarchand and David Martin, 'Selective genocide in Burundi' (Minority Rights Group, July 1974).

13. United Nations, 'Letter dated 25 July 1996 from the Secretary-General addressed to the President of the Security Council' (UN Security Council, 22 August 1996). 
Burundi's negotiated transition is the complex ethnic power-sharing scheme laid down in the 2000 Arusha Agreement and in the 2005 constitution. ${ }^{14}$ This includes a guaranteed $-50 / 50$ percent or $60 / 40$ percent representation of Hutu and Tutsi segments (and at some levels, also of the smaller Twa minority) ${ }^{15}$ in Parliament, in the government, in the local administration, and in the army. At the most senior executive level, a unique "grand coalition presidency" was engineered. The directly elected president must appoint two vice-presidents from different ethnic groups and from different political parties: one predominantly Hutu and one predominantly Tutsi.

Against all odds, the system designed on paper in Arusha has been well respected in practice. Ethnic integration and cohabitation within the new Burundian armed forces composed of former enemy armies has been remarkably smooth. ${ }^{16}$ Despite initial scepticism at the time of its signature, Arusha soon became the widely respected political and institutional roadmap for post-conflict Burundi. Ethnic cohabitation was even noticeable in informal settings where no quotas were imposed by Arusha. As much as political elites stirred and instrumentalized ethnic antagonism during the violent conflict, growing inter-elite trust and socialization in the atmosphere of the post-conflict "spirit of Arusha" trickled down beyond formal state institutions as a driver of political and social reconciliation.

Several features of the electoral crisis demonstrate the remarkable resilience of ethnic power sharing thus far. Political opposition to Nkurunziza's third mandate transcends ethnic boundaries. Civil society protests, while clearly more important in predominantly Tutsi neighbourhoods, also involved a large number of Hutu protesters. ${ }^{17}$ Despite the coup d'état, the military did not fall apart along ethnic lines, and the coup plotters included both Hutu and Tutsi figures. The fallout of the 2010 elections and the preelectoral crisis have given rise to a new kind of political bipolarity that is no longer Hutu-Tutsi. ${ }^{18}$ Identity politics remains predominant in Burundi but the main fault line has come to be determined by political partisanship rather than ethnic ties. After the 2010 elections, the fault line was adherence or opposition to the CNDD-FDD "system", as it was increasingly called.

14. For more details on the differences and similarities between the two "false twins", see Stef Vandeginste, 'Governing ethnicity after genocide: ethnic amnesia in Rwanda versus ethnic power-sharing in Burundi', fournal of Eastern African Studies 8, 2 (2014), pp. 263-77.

15. Stef Vandeginste, 'Political representation of minorities as collateral damage or gain: The Batwa in Burundi and Rwanda', Africa Spectrum 49, 1 (2014), pp. 3-25.

16. Cyrus Samii, 'Perils or promise of ethnic integration? Evidence from a hard case in Burundi', American Political Science Review 107, 3 (2013), pp. 558-73.

17. Compared to the inter-ethnic massacres from October 1993 onwards, the number of casualties of this electoral crisis remains limited, so far, which is in large part due to the almost total irrelevance of the ethnic dimension, so far.

18. Tomas van Acker, 'Understanding Burundi's predicament' (Royal Institute for International Relations, Africa Policy Brief No. 11, Brussels, June 2015). 
In the run-up to the 2015 elections, the fault line was support or opposition to Nkurunziza's third term.

As noted above, protests against a third presidential term were frequently framed as saving the Arusha Agreement. Seen from that perspective, the current crisis is essentially about safeguarding or ending Burundi's powersharing polity. Part of the CNDD-FDD leadership has hinted at the desirability of putting an end to some of the complexities of the Arusha-based institutional framework. For example, in November 2013, without any prior consultation, the party tabled a constitutional amendment that was widely perceived as an attack on Arusha. A majority of two-thirds in the national assembly and four-fifths in the senate is required for an amendment to the constitution. In March 2014, the proposal was rejected in Parliament by one vote, but the initiative opened Pandora's box, with many people suspecting CNDD-FDD of wanting to obtain full control over Parliament after the 2015 elections and to do away with Arusha once and for all. This situation resembles the one that Donald Horowitz sketches of a temporarily weak demographic majority (in this case the Hutu) agreeing to ethnic power sharing but regaining its full strength (in this case through elections) and trying to do away with the concessions made to the minority, yet facing the 'immobilism' of the power-sharing dispensation. ${ }^{19}$

When considering recent Burundian history, one can also imagine another CNDD-FDD ambition, namely a return to a de facto one-party state in combination with ethnic power sharing, the kind of system Burundi experienced for a couple of years prior to the introduction of multi-partyism in 1992. Indeed, particularly since the 2010 elections, the CNDD-FDD regime has become increasingly reminiscent of single-party rule in the late sixties, seventies and eighties: a de facto overlapping identity between the party and the state (in particular in the rural areas), military supremacy over civilian power, a largely cosmetic separation of powers, and a highly neopatrimonial governance style. ${ }^{20}$ If this trend is consolidated, mechanisms typical of consociational democracies will not be undone but rather "hijacked" to serve ethnic pacification under an increasingly authoritarian one-party rule. Because of the split Nkurunziza's personal ambitions caused within his own party, he may have made the realization of this scenario more difficult.

19. Donald Horowitz, 'Ethnic power sharing: Three big problems', fournal of Democracy 15, 2 (2014), pp. 5-20.

20. Testimonies by CNDD-FDD defectors systematically point to a parallel power structure, in which none of the - on paper exemplary - state institutions (including the electoral commission and the constitutional court) has the final word when major interests are at stake. Interviews, several CNDD-FDD defectors, Brussels, May and June 2015. 


\section{The dark side of power sharing}

The dark side of the use of power sharing as a conflict resolution tool became evident during the electoral crisis. The repeated use of power sharing in Burundi has clearly created a new mindset and an incentive structure among political elites. Leaving aside the ethnic dimension of the conflict and the peace process, Burundian politics for the past two decades has been dominated by discussions on how to share control of the state among elite actors and their networks. Positions in government, in the military, in the legislature, in the senior administration, and in the diplomatic service have been the main carrots used to stabilize the political arena in the aftermath of the coup d'état that removed Ndadaye in 1993, during the transitional period after the signature of the Arusha Agreement, and during the peace talks with the remaining rebel movements. As a result, political elite actors have internalized a very specific meaning of the concept of peace. For them, peace is the equilibrium in the allocation of power, state resources, and privileges. International mediation and peacebuilding was successful in so far as that equilibrium was not distorted, and in so far as additional foreign aid made the equilibrium more appetizing and therefore more easily agreeable among elite actors. ${ }^{21}$

Seen from that angle, elections are an almost inevitable source of instability. Despite constitutional guarantees on a multi-party coalition government, elections carry the risk of distorting the equilibrium. ${ }^{22}$ For some actors, elections lead to new claims and new opportunities, while, for others, elections constitute a threat. This is all the more true when election processes are - in reality or perceived as - unfree, unfair, and controlled by one of the parties, in this case the CNDD-FDD. From this perspective, the instability caused - or likely to be caused - by elections needs to be solved through power-sharing negotiations between opponents. This is clearly part of the strategy of several political actors involved in the Burundian crisis. Already in May 2014, two opposition leaders, Léonard Nyangoma and Alexis Sinduhije, called upon President Nkuruniza to establish a broad-based government of national unity to ease political tensions. In June 2015, another opposition politician speaking on behalf of the 'Arusha movement' suggested that he might be willing to accept a third presidential term reduced to two (instead of five) years in return for assurances of the opposition's participation in the interim coalition government. ${ }^{23}$ These

21. Alex de Waal, 'Mission without end? Peacekeeping in the African political marketplace', International Affairs 85, 1 (2009), pp. 99-123.

22. For a commentary on the 2010 elections from that angle, see Stef Vandeginste, 'Power sharing as a fragile safety valve in times of electoral turmoil: The costs and benefits of Burundi's 2010 elections', Fournal of Modern African Studies 49, 2 (2011), pp. 315-35.

23. Interview, Bujumbura-based political analyst, telephone interview, 22 June 2015. 
positions illustrate the elite perception that elections and power-sharing talks are in effect interchangeable avenues through which to gain access to power.

Burundi thus lends support to the view that elite socialization with the repeated use of power sharing may have perverse demonstration effects. ${ }^{24} \mathrm{It}$ is also possible that the repeated use of power sharing increases the prospects of a return to violent conflict for two reasons. First, recent history shows that Burundian politicians do not readily negotiate without the prior use of armed violence. They realize that military "nuisance" capacity determines their bargaining position around the negotiations table. In 2010, the opposition's election boycott was ill-prepared and not supported by any military nuisance capacity. It failed as a result. The opposition is unlikely to make the same mistake in 2015. Second, history shows that as soon as a share in power can be obtained through negotiations, impunity for past abuses - including those committed in order to obtain a credible position around the negotiations table - is guaranteed. Indeed, for the past twenty-five years, no senior government official, military officer, or rebel leader has been held accountable for human rights abuses in Burundi. ${ }^{25}$

These negative legacies of the power-sharing model of conflict resolution have been exacerbated by the fact that although the Arusha Agreement is rightly praised for solving Burundi's "old" problems, and remains necessary in order to reassure ethnic minorities and to prevent the country from returning to past tensions, it did not offer a solution to some of the other governance deficiencies that have emerged ever more clearly during the ongoing crisis, such as the rise in militarism and the weakness of the rule of law. As a result, there are few barriers to the creeping return of authoritarian government.

\section{Conclusion and possible ways forward}

Burundi's pre-electoral (but presumably also post-electoral) crisis was occasioned by President Nkurunziza's third-term ambitions, opposed by a variety of social and political actors, including members of his own political party. International (though not unanimous) pressure did not have any impact on the incumbent president's intentions. Nor did the prospect of a

24. Dennis Tull and Andreas Mehler, 'The hidden costs of power-sharing: Reproducing insurgent violence in Africa', African Affairs 104, 416 (2005), pp. 375-98; AU Panel of the Wise, 'Election-related disputes and political violence. Strengthening the role of the African Union in Preventing, Managing and Resolving Conflict' (African Union, July 2010), p. 27.

25. Stef Vandeginste, 'Burundi's Truth and Reconciliation Commission: How to shed light on the past while standing in the dark shadow of politics?', International fournal of Transitional Fustice 6, 2 (2012), pp. 355-65. See, more generally, Stef Vandeginste and Chandra Sriram, 'Power sharing and transitional justice: A clash of paradigms?', Global Governance 17 (2011), pp. 489-505. 
continuously unstable and hostile capital city. What's next? The country's recent history demonstrates the complementary role that political violence, the ballot box, and power-sharing negotiations have played in securing access to power. In the toolbox of Burundi's elite actors, these are three strategies with which most leaders have become familiar over the past two decades. Of the three, power sharing has had the most stabilizing effect. Given this, two medium-term scenarios come to mind, both of which reflect the above analysis of Burundi's experience with power sharing, despite the differences between them.

In a first scenario, the incumbent president and what remains of his CNDD-FDD party consolidate their grip on the state through the 2015 elections. After the generally praised 2005 elections and the partly boycotted 2010 elections, Burundi then becomes a textbook example of autocratization through elections. ${ }^{26}$ In this scenario, the initial failure of the CNDD-FDD to obtain a military victory on the battlefield is remedied through the ballot box. As suggested above, the radical wing now dominating the party may either maintain ethnic power sharing within the de facto one-party system or, alternatively, renege on Arusha at the risk of sowing the seeds of renewed grievance-based insurgency. In this scenario, the reduction of foreign aid volumes may also reduce the ability of the regime to fund and sustain its own neo-patrimonial system.

At the time of writing of this article, many political and civil society figures have come to the conclusion that President Nkurunziza can only be removed through the use of armed force. Whether after a short or lengthy period of armed confrontation, and whether with or without President Nkurunziza, it is most likely that, for lack of better alternatives, old recipes will again be called upon to re-stabilize Burundi's political landscape. A new round of power-sharing negotiations after a period of post-electoral violence risks delaying the internalization of democratic electoral competition as the sole legitimate avenue to political power once again. One should hope that, if this second scenario comes to pass, the ethnic power-sharing acquis that has emerged will survive a further round of violence and negotiations. There are some indications that it might: another conclusion to be drawn from Burundi's recent history is that, although the Arusha Agreement has not been able to solve several governance-related challenges, its ethnic pacification model has so far stood the test of the crisis and prevented electoral violence from transforming into ethnic violence, a major achievement in a country characterized by ethno-political strife for several decades.

26. Staffan Lindberg, Democratization by elections: A new mode of transition (Johns Hopkins University Press, Baltimore, MD, 2009). 